\title{
Minocycline modulates antigen-specific CTL activity through inactivation of mononuclear phagocytes in patients with HTLV-I associated neurologic disease
}

Yoshimi Enose-Akahata ${ }^{1}$, Eiji Matsuura ${ }^{1,2}$, Yuetsu Tanaka ${ }^{3}$, Unsong $\mathrm{Oh}^{1,4}$ and Steven Jacobson ${ }^{1 *}$

\begin{abstract}
Background: The activation of mononuclear phagocytes (MPs), including monocytes, macrophages and dendritic cells, contributes to central nervous system inflammation in various neurological diseases. In HTLV-l-associated myelopathy/tropical spastic paraparesis (HAM/TSP), MPs are reservoirs of HTLV-I, and induce proinflammatory cytokines and excess T cell responses. The virus-infected or activated MPs may play a role in immuneregulation and disease progression in patients with HTLV-l-associated neurological diseases.
\end{abstract}

Results: Phenotypic analysis of CD14 $4^{+}$monocytes in HAM/TSP patients demonstrated high expression of $\mathrm{CX}_{3} \mathrm{CR} 1$ and HLA-DR in $\mathrm{CD} 14^{\text {low }} \mathrm{CD} 16^{+}$monocytes, compared to healthy normal donors (NDs) and asymptomatic carriers (ACs), and the production of TNF- $\alpha$ and IL- $1 \beta$ in cultured CD14 $4^{+}$cells of HAM/TSP patients. CD14 ${ }^{+}$cells of HAM/ TSP patients also showed acceleration of HTLV-I Tax expression in CD4 ${ }^{+} \mathrm{T}$ cells. Minocycline, an inhibitor of activated MPs, decreased TNF- $\alpha$ expression in CD14 ${ }^{+}$cells and IL-1 $\beta$ release in PBMCs of HAM/TSP patients. Minocycline significantly inhibited spontaneous lymphoproliferation and degranulation/IFN- $\gamma$ expression in $\mathrm{CD}^{+}$ T cells of HAM/TSP patients. Treatment of minocycline also inhibited IFN- $\gamma$ expression in CD8 ${ }^{+}$T cells of HAM/TSP patients after Tax11-19 stimulation and downregulated MHC class I expression in CD14 ${ }^{+}$cells.

Conclusion: These results demonstrate that minocycline directly inhibits the activated MPs and that the downregulation of MP function can modulate $C D 8^{+} \mathrm{T}$ cells function in HAM/TSP patients. It is suggested that activated MPs may be a therapeutic target for clinical intervention in HAM/TSP.

Keywords: HTLV-I, HAM/TSP, monocyte, CTL, minocycline

\section{Background}

The human T cell lymphotropic virus I (HTLV-I) infects 20 million people worldwide of which the majority of infected individuals are asymptomatic carriers (AC) of the virus [1]. However, in a small percentage of infected individuals, HTLV-I is the etiologic agent of adult T cell leukemia/lymphoma (ATL) [2] and a chronic, progressive neurological disease termed HTLV-I-associated myelopathy/tropical spastic paraparesis (HAM/TSP) $[3,4]$. Patients with HAM/TSP demonstrate high HTLV-

\footnotetext{
* Correspondence: JacobsonS@ninds.nih.gov

'Viral Immunology Section, Neuroimmunology Branch, National Institute of Neurological Disorders and Stroke, National Institutes of Health, Bethesda, Maryland 20892 USA

Full list of author information is available at the end of the article
}

I proviral DNA load, high HTLV-I Tax mRNA load, and high virus-specific immune responses, including increased production of inflammatory cytokines and expansion of Tax-specific $\mathrm{CD} 8^{+} \mathrm{T}$ cells [5-9]. A high frequency of $\mathrm{CD}^{+}{ }^{+} \mathrm{T}$ cells is persistently infected and exhibits high expression of Tax protein [10]. These infected cells are responsible for the increased lymphocyte proliferation in patients with HAM/TSP [11]. High frequency of activated $\mathrm{CD} 8^{+} \mathrm{T}$ cells in peripheral blood and even higher in cerebrospinal fluid has been reported [12]. In addition to these strong HTLV-I-associated $\mathrm{T}$ cell responses, it has been suggested that mononuclear phagocytes (MPs; monocytes, dendritic cells, tissue macrophages and microglia) are also involved in the

\section{Ciomed Central}


pathogenesis of HAM/TSP. MPs are infected with HTLV-I in vitro and in vivo [13-18], and dendritic cells have been shown to effectively transfer cell-free virus to $\mathrm{CD}^{+}{ }^{+} \mathrm{T}$ cells [18]. HTLV-I-infected dendritic cells can stimulate both $\mathrm{CD}^{+}$and $\mathrm{CD} 8^{+} \mathrm{T}$ cells [17]. Moreover, HTLV-I infection of CD14 ${ }^{+}$cells and the concomitant expression of IL-15 mediate spontaneous degranulation and IFN- $\gamma$ expression in $\mathrm{CD}^{+} \mathrm{T}$ cells [19]. Pathological studies have confirmed the presence of inflammatory monocyte/macrophages as well as $\mathrm{CD} 4^{+} \mathrm{T}$ cells and $\mathrm{CD}^{+}{ }^{+} \mathrm{T}$ cells in the central nervous system (CNS) of HAM/TAP patients $[20,21]$. These findings suggest that virus-infected or activated MPs may play a role in immune regulation and disease progression in patients with HTLV-I-associated neurological diseases.

MPs are widely distributed immune cells that maintain tissue homeostasis and provide a first line of defense against invading pathogens. MPs have been shown to present antigens bound by major histocompatibility complex (MHC) molecules and to activate $\mathrm{CD} 4^{+} \mathrm{T}$ helper cells or cytotoxic $\mathrm{CD}^{+} \mathrm{T}$ cells [22]. The abilities to combat microbial infection and clear debris are intimately tied to MP activation and follow degenerative, inflammatory, infectious, and ischemic insults. However, under inflammatory conditions, differential MP population and activation of MPs are related to immunopathogenesis and disease progression. Human peripheral monocytes contain two major subsets, the $\mathrm{CD} 14^{+} \mathrm{CD} 16^{-}$and $\mathrm{CD} 14^{\text {low }} \mathrm{CD} 16^{+}$monocytes [23]. The $\mathrm{CD} 14^{\text {low }} \mathrm{CD} 16^{+}$monocytes express higher levels of proinflammatory cytokines than $\mathrm{CD} 14^{+} \mathrm{CD} 16^{-}$monocytes, with a higher capacity for antigen presentation, and are increased in inflammatory and infectious diseases in humans [24]. Macrophage/microglial inflammatory activities have been shown to influence a number of neurodegenerative diseases including human immunodeficiency virus (HIV)-associated dementia, Alzheimer's disease, Parkinson's disease, stroke, brain and spinal cord trauma [25]. In HAM/TSP, the expression of proinflammatory cytokines such as IL- $1 \beta$, TNF- $\alpha$ and IFN- $\gamma$ is detected in peripheral blood mononuclear cells (PBMCs) as well as in perivascular infiltrating macrophages and microglia in the spinal cords of patients with HAM/TSP [26,27]. Moreover, HTLV-I Tax has been reported to induce the human proIL-1 $\beta$ gene promoter in monocytic cells [28]. Thus, MPs of patients with HAM/TSP might be activated under inflammatory conditions and play a role in immunopathogenesis of this disorder.

In this study, we demonstrate that $\mathrm{CD} 14^{+}$cells of patients with HAM/TSP showed an inflammatory phenotype as evidenced by high expression of HLA-DR and $\mathrm{CX}_{3} \mathrm{CR} 1$, proinflammatory cytokines (TNF- $\alpha$ and IL-1 $\beta$ ) and acceleration of HTLV-I Tax expression in CD $4^{+} \mathrm{T}$ cells. Minocycline, which is tetracycline derivative and a known inhibitor of activated macrophage/microglia [29], significantly inhibited TNF- $\alpha$ and IL- $1 \beta$ expressions in cultured $\mathrm{CD} 14^{+}$cells of patients with HAM/TSP. Moreover, treatment with minocycline demonstrated inhibition of IFN- $\gamma$ expression in $\mathrm{CD}^{+} \mathrm{T}$ cells of patients with HAM/TSP, resulting from inhibition of MP activation by minocycline. These results demonstrate that $\mathrm{CD} 8^{+} \mathrm{T}$ cell activation of patients with HAM/TSP can be suppressed through down-regulation of MP activation, and suggest a novel treatment strategy in patients with HTLV-I associated neurological disease.

\section{Results}

\section{High $\mathrm{CX}_{3} \mathrm{CR} 1$ and HLA-DR expression in monocytes of} patients with HAM/TSP

To characterize CD14 ${ }^{+}$cell subsets in PBMCs of HAM/ TSP patients, the expression of monocyte markers CD14 and CD16 was examined by flow cytometry in NDs, ACs and patients with HAM/TSP. Figure 1A demonstrates a representative dot plot of MP populations of a ND and a patient with HAM/TSP. Group analysis did not show significant differences between $\mathrm{CD} 14^{+} \mathrm{CD} 16^{-}$ and $\mathrm{CD} 14^{\mathrm{low}} \mathrm{CD} 16^{+}$frequencies in MP population among NDs, ACs, and patients with HAM/TSP (data not shown). Previous reports demonstrated that $\mathrm{CD} 14^{\text {low }} \mathrm{CD} 16^{+}$monocytes expressed higher levels of $\mathrm{CX}_{3} \mathrm{CR} 1$ (a fractalkine receptor) and HLA-DR, proinflammatory cytokines and higher potency in antigen presentation in human inflammatory and infectious diseases $[23,24]$. We therefore compared $\mathrm{CX}_{3} \mathrm{CR} 1$ and HLA-DR expression on $\mathrm{CD} 14^{\mathrm{low}} \mathrm{CD} 16^{+}$monocytes among the groups. A representative dot plot shows that both $\mathrm{CX}_{3} \mathrm{CR} 1$ and HLA-DR expression was higher in $\mathrm{CD} 14^{\text {low }}{ }^{2} \mathrm{CD} 16^{+}$subset of a patient with HAM/TSP than that of a ND (Figure 1A). In NDs, the CD14 ${ }^{\text {low }} \mathrm{CD} 16^{+}$subset expressed both $\mathrm{CX}_{3} \mathrm{CR} 1$ and HLA-DR (mean+/-standard deviation $(\mathrm{SD})=7.572+/-6.748, \mathrm{n}=10$; Figure $1 \mathrm{~B})$. In contrast, the $\mathrm{CD} 14^{\text {low }} \mathrm{CD} 16^{+}$subset of patients with $\mathrm{HAM} / \mathrm{TSP}$ had significantly higher levels of both $\mathrm{CX}_{3} \mathrm{CR} 1$ and HLA-DR expression (mean $+/$-SD $=51.88+/-24.42$, $\mathrm{n}=12$; Figure $1 \mathrm{~B}$ ). $\mathrm{CX}_{3} \mathrm{CR} 1$ and HLA-DR expression in $\mathrm{CD} 14^{\text {low }}{ }^{\mathrm{CD}} 16^{+}$subset of ACs was significantly lower than those in patients with HAM/TSP, and at comparable levels with those in NDs (mean+/-SD = 15.04+/-13.31, $\mathrm{n}=6$; Figure 1B). These results demonstrated that the $\mathrm{CD} 14{ }^{\text {low }} \mathrm{CD} 16^{+}$subset in patients with HAM/TSP showed significantly high expression of $\mathrm{CX}_{3} \mathrm{CR} 1$ and HLA-DR, compared to NDs and ACs.

Given the high expression of $\mathrm{CX}_{3} \mathrm{CR} 1$ and HLA-DR on the $\mathrm{CD} 14^{\text {low }} \mathrm{CD} 16^{+}$subset in patients with HAM/TSP, we asked whether these changes in MP subsets were related to biomarkers of disease activity in HAM/TSP. We previously reported that $\mathrm{CD} 14^{+}$cells induced degranulation and IFN- $\gamma$ expression in $\mathrm{CD}^{+} \mathrm{T}$ cells of patients with HAM/TSP in vitro [19]. We therefore analyzed the 
A

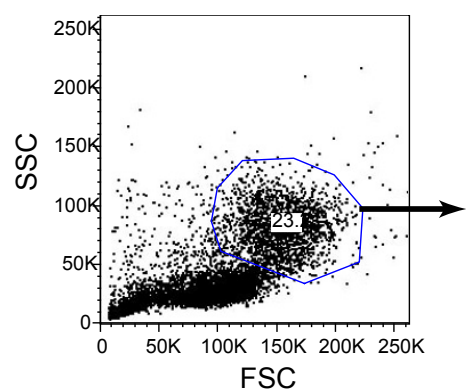

FSC

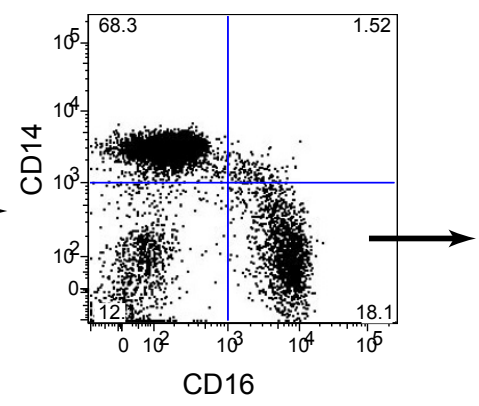

CD16

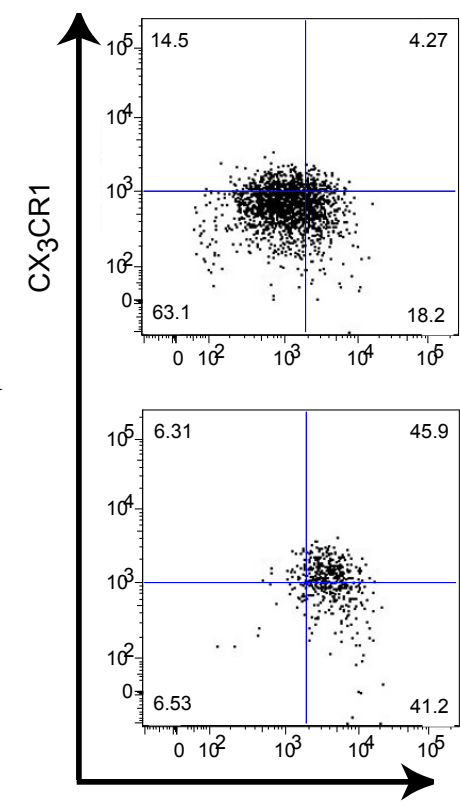

HLA-DR$$
2
$$

B

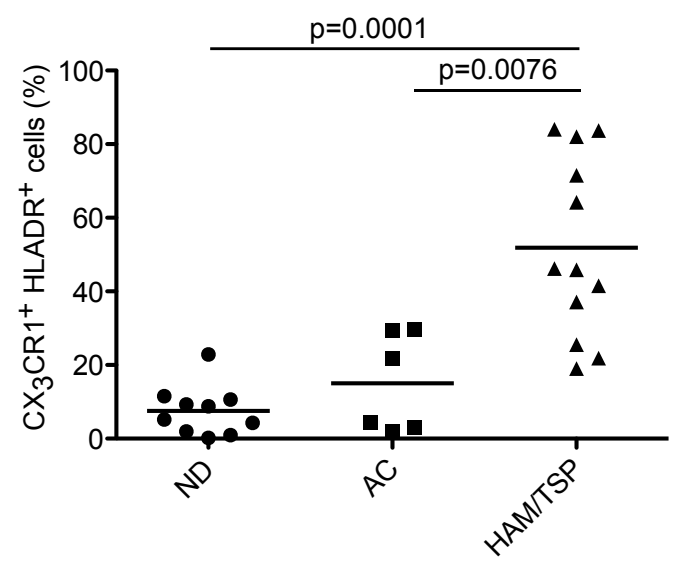

D

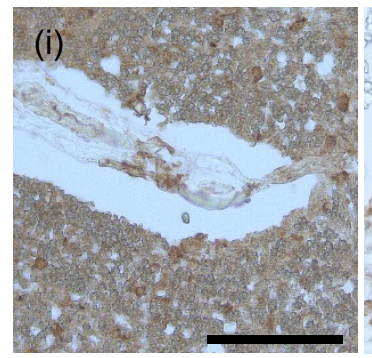

C

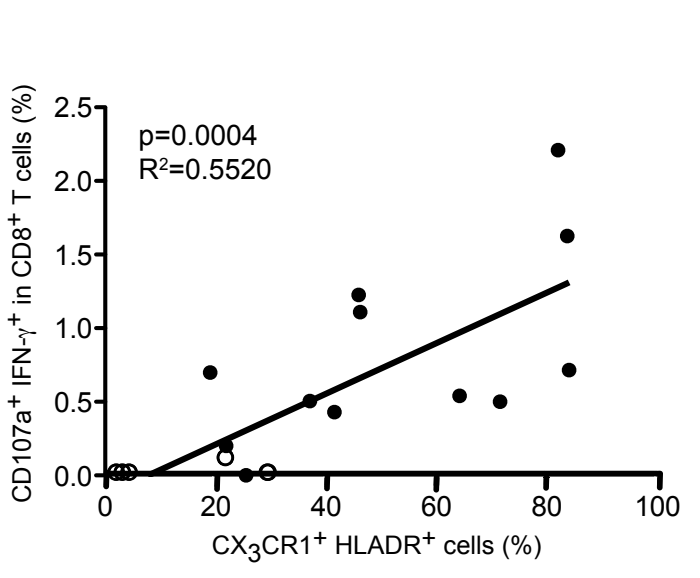

$\mathrm{HAM} / \mathrm{TSP}$

ND

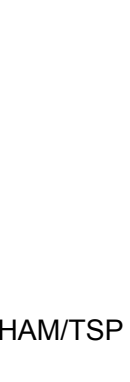


relationship between $\mathrm{CX}_{3}$ CR1/HLA-DR expression on $\mathrm{CD} 14{ }^{\text {low }} \mathrm{CD} 16^{+}$subset and degranulation/IFN- $\gamma$ expression in $\mathrm{CD}^{+} \mathrm{T}$ cells of HTLV-I-infected patients. $\mathrm{CX}_{3} \mathrm{CR} 1 / \mathrm{HLA}-\mathrm{DR}$ expression on $\mathrm{CD} 14^{\text {low }}{ }^{\mathrm{CD}} 16^{+}$subset was significantly correlated with degranulation/IFN- $\gamma$ expression in $\mathrm{CD}^{+} \mathrm{T}$ cells of HTLV-I-infected patients (Figure 1C; $\mathrm{P}=0.0004, \mathrm{R}^{2}=0.552$ ). These results suggested that activation of MP in vivo could be related to $\mathrm{CD}^{+} \mathrm{T}$ cell activation of patients with neurologic inflammatory disease.

Immunohistochemical analysis further demonstrated that $\mathrm{CX}_{3} \mathrm{CR} 1^{+}$cells were detected in the spinal cord of a patient with HAM/TSP (Figure 1D). $\mathrm{CX}_{3} \mathrm{CR} 1^{+}$cells were detected around the blood vessels and in the parenchyma and the meninges in the HAM/TSP spinal cord (Figure 1Di and 1Dii, respectively), suggesting a recruitment of $\mathrm{CX}_{3} \mathrm{CR}^{+}$cells from the periphery to the spinal cord parenchyma and meninges. Moreover, $\mathrm{CX}_{3} \mathrm{CR} 1^{+}$cells in the parenchyma were morphologically bigger (Figure 1Diii) and positive for CD68 (Figure 1Div), probably corresponding to MPs. These results further support the idea that $\mathrm{CX}_{3} \mathrm{CR} 1^{+}$cells might be recruited from peripheral blood to the spinal cord in patients with HAM/TSP.

\section{CD14 ${ }^{+}$cells express TNF- $\alpha$ and IL- $1 \beta$ and increase HTLV-I Tax expression in $\mathrm{CD}^{+}{ }^{+} \mathrm{T}$ cells of patients with HAM/TSP}

To further investigate MP activation in HAM/TSP patients, we examined TNF- $\alpha$ and IL- $1 \beta$ expression in cultured PBMCs of ND and HAM/TSP patients. After culture of total PBMCs for 24 hours, the frequency of $\mathrm{CD} 14^{+}$cells that expressed TNF- $\alpha$ was first examined by flow cytometry. CD $14^{+}$cells expressing TNF- $\alpha$ was significantly elevated in HAM/TSP patients, compared to NDs (Figure 2A). IL-1 $\beta$ was detected in PBMC culture supernatants of HAM/TSP patients but not of NDs (Figure $2 B$ ). Since relative expression of IL- $1 \beta$ mRNA dramatically increased in $\mathrm{CD} 14^{+}$cells after culture (data not shown), IL-1 $\beta$ detected in the culture supernatants would be released from the MPs of HAM/TSP patients.

In addition to the production of various proinflammatory cytokines, activated or virus-infected MPs, such as infection with HIV, effectively transfer or promote productive virus upon interaction with $\mathrm{T}$ cells $[30,31]$. Although $\mathrm{CD}_{1} 4^{+}$cells of patients with HAM/TSP are activated and also infected with HTLV-I at low levels, we wished to determine if there would be an increase in HTLV-I production in CD $4^{+} \mathrm{T}$ cells of patients with $\mathrm{HAM} / \mathrm{TSP}$ after interaction with autologous $\mathrm{CD} 14^{+}$cells. To address whether $\mathrm{CD} 14^{+}$cells promote HTLV-I production in $\mathrm{CD}^{+} \mathrm{T}$ cells of patients with HAM/TSP, we examined HTLV-I Tax expression of $\mathrm{CD} 4{ }^{+} \mathrm{CD} 25^{+} \mathrm{T}$ cells and $\mathrm{CD} 4^{+} \mathrm{CD} 25^{-} \mathrm{T}$ cells cocultured with or without autologous $\mathrm{CD}^{+} 4^{+}$cells of patients with HAM/TSP, compared to those of ACs. As shown in Figure 2Ci, in patients with HAM/TSP, 5.8-9.5\% of $\mathrm{CD} 4{ }^{+} \mathrm{CD} 25^{+} \mathrm{T}$ cells expressed HTLV-I Tax proteins at baseline. After coculture with autologous CD14. ${ }^{+}$cells, HTLV-I Tax expression was dramatically increased in $\mathrm{CD} 4{ }^{+} \mathrm{CD} 25^{+} \mathrm{T}$ cells (14.1-15.9\%, p = 0.0226; Figure 2Ci). While HTLV-I Tax expression was also detected in $0.8-4.4 \%$ of $\mathrm{CD} 4^{+} \mathrm{CD} 25^{-}$ $\mathrm{T}$ cells, an increase after coculture with $\mathrm{CD} 14^{+}$cells was lower than in $\mathrm{CD} 4{ }^{+} \mathrm{CD} 25^{+} \mathrm{T}$ cells (Figure $2 \mathrm{Cii}$ ). Since the increase of Tax expression was not detected in $\mathrm{CD} 4^{+} \mathrm{T}$ cells without cell-cell contact with $\mathrm{CD} 14^{+}$cells (data not shown), the increased expression of HTLV-I Tax in $\mathrm{CD} 4^{+} \mathrm{T}$ cells by the addition of $\mathrm{CD} 14^{+}$cells was celldependent. By contrast, both $\mathrm{CD} 4{ }^{+} \mathrm{CD} 25^{+} \mathrm{T}$ cells and $\mathrm{CD} 4^{+} \mathrm{CD} 25^{-} \mathrm{T}$ cells of ACs showed lower expression of Tax proteins $(<1 \%)$, which did not change after coculture with autologous $\mathrm{CD} 14^{+}$cells (Figure 2C). Thus, CD14 ${ }^{+}$ cells could accelerate Tax expression in HTLV-I-infected $\mathrm{CD} 4^{+} \mathrm{T}$ cells of patients with HAM/TSP.

\section{Minocycline inhibited MP activation and spontaneous lymphocyte proliferation of patients with HAM/TSP}

Since various therapeutic agents have been developed for neuroinflammatory diseases specifically aimed at the inhibition of activated MPs, we attempted to examine the inhibition of MP function in patients with HAM/ TSP using minocycline, which is known as an inhibitor of monocyte/macrophage activation. To evaluate inhibitory effect of minocycline on activated MP of patients with HAM/TSP, we examined TNF- $\alpha$ expression in cultured PBMCs of patients with HAM/TSP by treatment with minocycline. As shown in Figure 3A, the frequency of $\mathrm{CD}_{14}{ }^{+}$cells expressing TNF- $\alpha$ was significantly inhibited at $10 \mu \mathrm{M}$ of minocycline treatment in HAM/ TSP patients (Figure 3A; closed bar, $\mathrm{p}=0.0313$ ). The cultured $\mathrm{CD}^{+} \mathrm{T}$ cells also expressed TNF- $\alpha$, but minocycline did not inhibit TNF- $\alpha$ expression in $\mathrm{CD} 4^{+} \mathrm{T}$ cells (Figure 3A; opened bar). As demonstrated previously (Figure $2 \mathrm{~B}$ ), IL-1 $\beta$ was detected in the supernatants of cultured PBMCs of patients with HAM/TSP; the release of IL- $1 \beta$ from these cultured HAM/TSP PBMCs was also inhibited by $10 \mu \mathrm{M}$ of minocycline treatment $(\mathrm{p}=0.0078$; Figure $3 \mathrm{~B})$. These results demonstrated that minocycline inhibited the expression of proinflammatory cytokines from MPs, but not from $\mathrm{CD} 4^{+} \mathrm{T}$ cells, of patients with HAM/TSP.

An additional established measure of HAM/TSP T cell activation ex vivo is the well-described observations of increased spontaneous lymphoproliferation [5]. In addition to the expression of HTLV-I Tax and a variety of cytokines in PBMCs of HTLV-I-infected patients that are associated with spontaneous lymphoproliferation [32-34], the activation of MP is also involved in spontaneous 
B
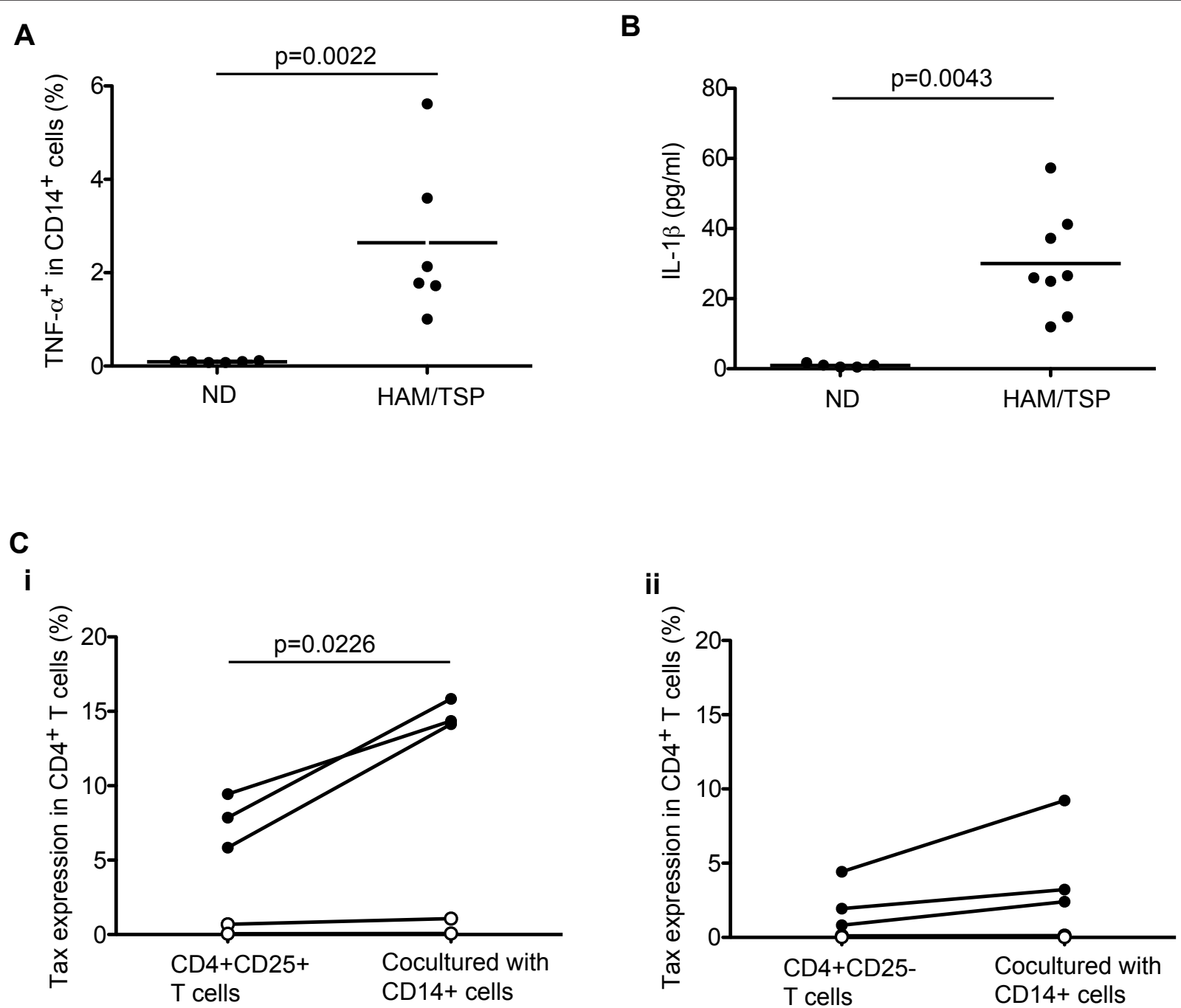

Figure 2 Activated $\mathrm{CD}_{14}{ }^{+}$cells in patients with HAM/TSP. (A) TNF- $\alpha$ expression in CD14 ${ }^{+}$cells of NDs and HAM/TSP patients after culture for 24 hours. The data were obtained from six NDs and six HAM/TSP patients. CD14 ${ }^{+}$cells expressing TNF- $\alpha$ was significantly elevated in HAM/TSP patients, compared to NDs by Mann-Whitney test $(p=0.0022)$. The horizontal line represents the mean. (B) Detection of IL-1 $1 \beta$ in PBMC culture supernatants of NDs and HAM/TSP patients after culture for 24 hours. The data were obtained from five NDs and eight HAM/TSP patients. IL-1 $\beta$ expression in HAM/TSP patients was significantly higher in those cells of NDs by Mann-Whitney test $(p=0.0043)$. The horizontal line represents the mean. (C) Tax expressions in $C D 4^{+} C D 25^{+} \mathrm{T}$ cells (i) and $\mathrm{CD} 4^{+} \mathrm{CD} 25^{-} \mathrm{T}$ cells (ii) cocultured with or without autologous CD $14^{+}$cells of $\mathrm{ACs}(\mathrm{n}=$ 2, opened circle) and patients with HAM/TSP $(n=3$, closed circle) for 18 hours.

lymphoproliferation of patients with HAM/TSP [5]. To address the inhibitory effects of minocycline on spontaneous lymphoproliferation, uptake of $\left[{ }^{3} \mathrm{H}\right]$ thymidine as a marker of proliferation was examined in PBMCs of two patients with HAM/TSP after treatment with minocycline. In minocycline-treated HAM/TSP PBMCs, the spontaneous lymphoproliferation was inhibited in a dosedependent manner (Figure 3C). Since the treatment with minocycline did not inhibit HTLV-I Tax expression in both $\mathrm{T}$ cells and $\mathrm{CD} 14^{+}$cells (data not shown), these results showed that minocycline can downregulate MP activation, such as proinflammatory cytokine expression.
Minocycline inhibits spontaneous degranulation and IFN- $\gamma$ expression in $\mathrm{CD}^{+} \mathrm{T}$ cell of patients with HAM/TSP

MPs play an indispensable role in the induction of antigen-specific CTL responses by capturing viral antigen and presenting peptide through $\mathrm{MHC}$ class I to $\mathrm{CD}^{+} \mathrm{T}$ cells. In patients with HAM/TSP, HTLV-I-infected or activated MPs collaborate with $\mathrm{CD}^{+} \mathrm{T}$ cell to induce spontaneous degranulation and high IFN- $\gamma$ expression [19]. Since we have demonstrated that minocycline has inhibitory effects on activated MPs (Figure 3), minocycline might also inhibit MP function such as triggering adaptive immune responses. To determine if inhibition of MPs affects $\mathrm{CD} 8^{+}$ 


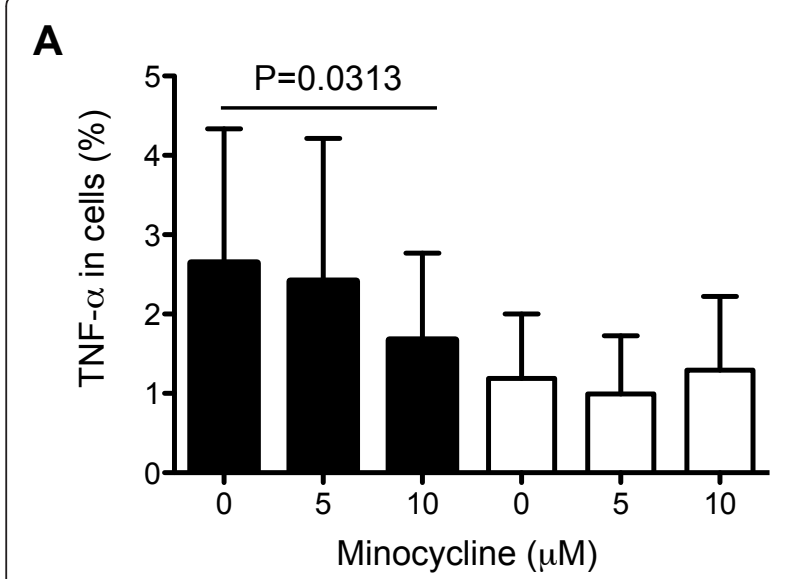

C

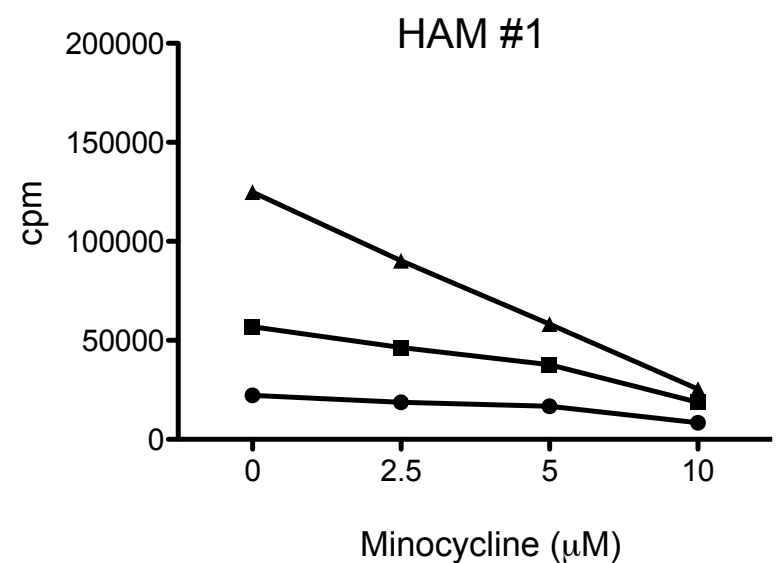

B
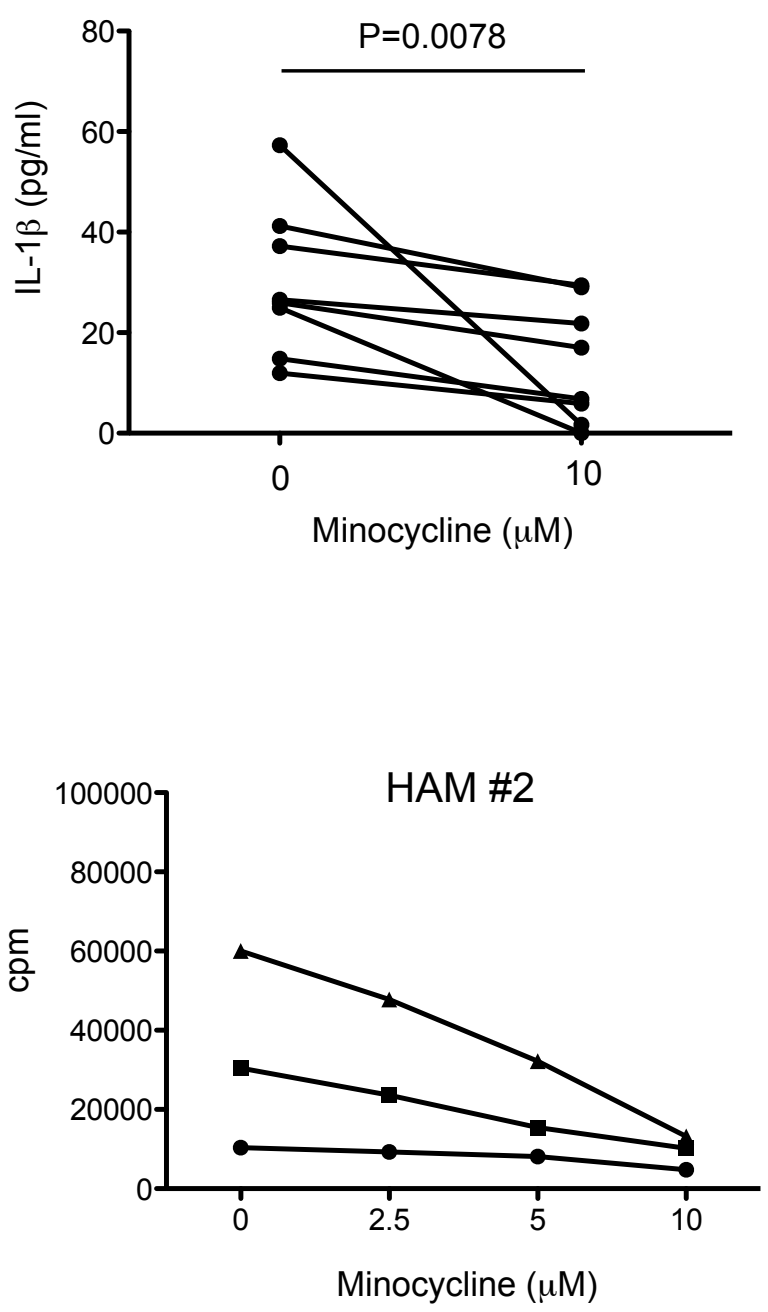

Figure 3 Minocycline inhibited TNF- $\alpha$ expression and IL-1 $\beta$ release in patients with HAM/TSP. (A) Dose-dependent inhibitory effects of minocycline on TNF- $\alpha$ expressions in CD14 $4^{+}$cells (closed bar) and CD4 $4^{+}$T cells (opened bar) of HAM/TSP patients $(n=6)$. The PBMCs were cultured with 0,5 and $10 \mu \mathrm{M}$ of minocycline for 24 hours. The frequency of CD14 $4^{+}$cells expressing TNF- $\alpha$ was significantly inhibited at $10 \mu \mathrm{M}$ of minocycline treatment in HAM/TSP patients ( $p=0.0313$; Wilcoxon matched-pairs signed rank test). Error bars represent SD. (B) Inhibition of IL-1 $\beta$ release in PBMC culture supernatants of HAM/TSP patients by $10 \mu \mathrm{M}$ of minocycline after culture for 24 hours $(n=8)$. The release of IL-1 $1 \beta$ from these cultured HAM/TSP PBMCs was significantly inhibited by minocycline treatment ( $p=0.0078$; Wilcoxon matched-pairs signed rank test). (C) Inhibitory effects of minocycline on spontaneous lymphoproliferation in HAM/TSP patients. The PBMCs from two HAM/TSP patients (HAM\#1 and \#2) were cultured with $0,2.5,5$ and $10 \mu \mathrm{M}$ of minocycline, and pulsed with $1 \mu \mathrm{Ci}\left[{ }^{3} \mathrm{H}\right]$ thymidine for 4 hours at 3 days (closed circle), 4 days (closed square) and 5 days (closed triangle). The average cpm from each well in triplicate was plotted.

T cell responses in HAM/TSP, we examined the effect of minocycline on expression of CD107a, a marker of degranulation, and IFN $-\gamma$ in $\mathrm{CD}^{+} \mathrm{T}$ cells of patients with HAM/TSP. As previously reported [19], CD107a and IFN$\gamma$ were spontaneously expressed in $\mathrm{CD}^{+} \mathrm{T}$ cells of a patient with HAM/TSP after PBMC culture for 24 hours without any exogenous stimuli, but not in those cells of a ND. In Figure 4A, representative dot plots show that treatment with minocycline inhibited CD107a and IFN- $\gamma$ expression in $\mathrm{CD}^{+} \mathrm{T}$ cells of a patient with HAM/TSP. Group analysis showed significant, dose-dependent, inhibitory effects of minocycline on spontaneous degranulation and IFN- $\gamma$ expression in $\mathrm{CD}^{+} \mathrm{T}$ cells of patients with HAM/TSP (Figure 4B). These results demonstrated that spontaneous degranulation and IFN- $\gamma$ expression in $\mathrm{CD}^{+} \mathrm{T}$ cells of patients with HAM/TSP were inhibited by treatment with minocycline.

\section{Minocycline inhibits antigen-specific $\mathrm{CD}^{+} \mathrm{T}$ cells responses in patients with HAM/TSP}

To confirm whether treatment with minocycline could inhibit antigen-specific $\mathrm{CD}^{+} \mathrm{T}$ cell responses of 
A

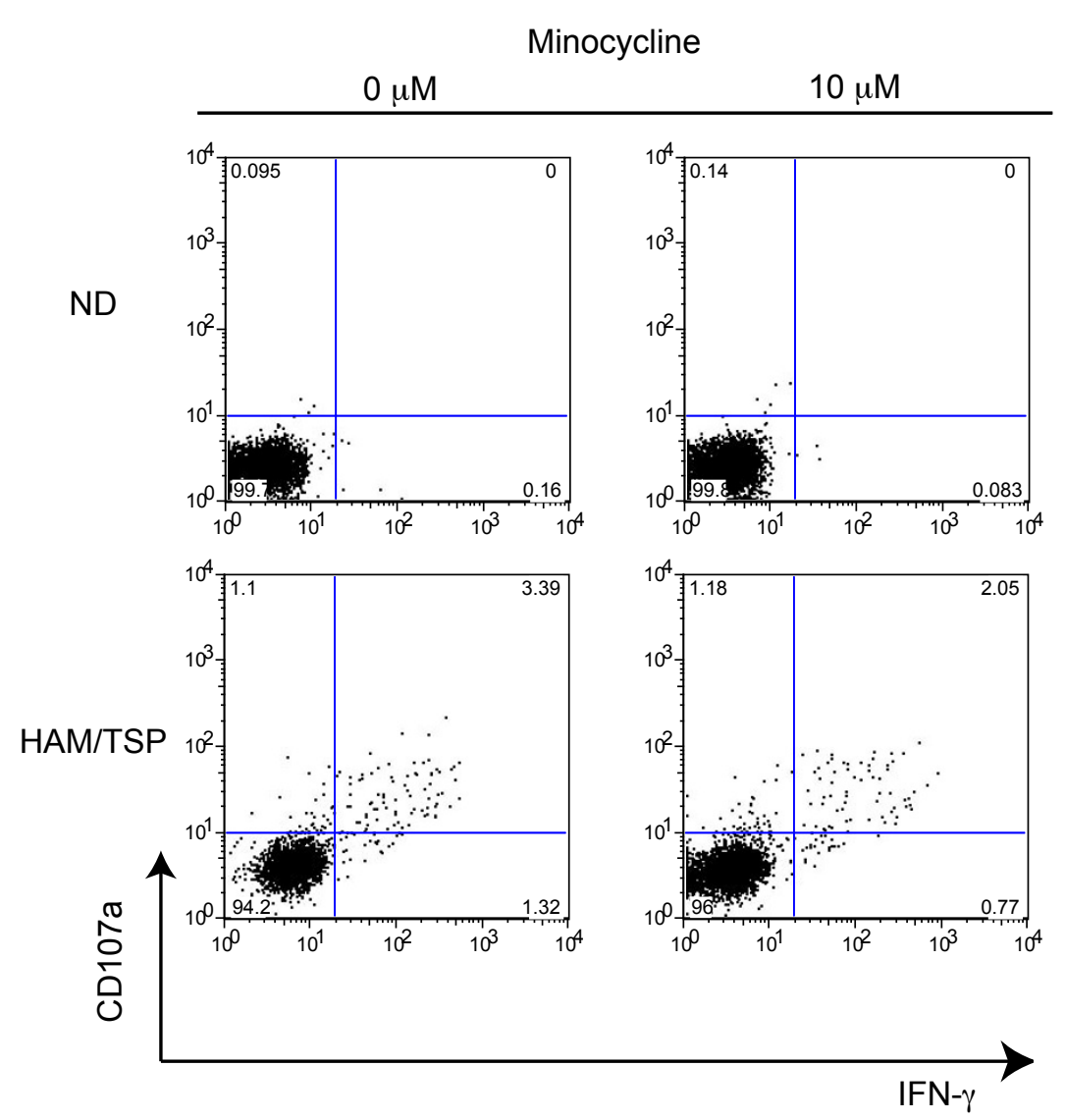

B

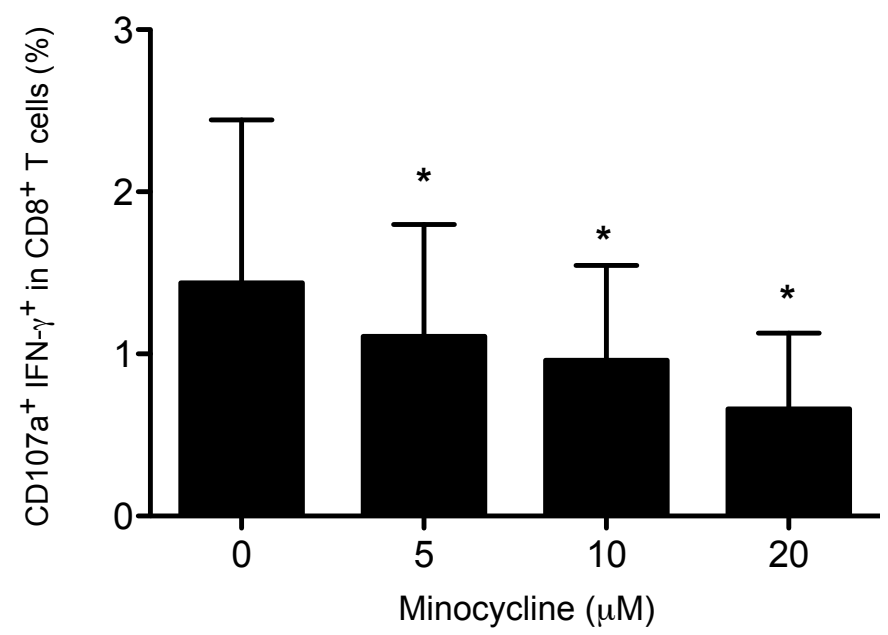

Figure 4 Minocycline inhibited spontaneous degranulation/IFN- $\gamma$ expression in $\mathrm{CD}^{+} \mathrm{T}$ cells of patients with HAM/TSP. (A) Representative dot plots of CD107a and IFN- $\gamma$ expression in CD8 ${ }^{+}$T cells of a ND and a HAM/TSP patient after culture for 24 hours with or without $10 \mu \mathrm{M}$ of minocycline. (B) Inhibitory effects of minocycline on degranulation/IFN- $\gamma$ expression in CD8 ${ }^{+} \mathrm{T}$ cells of eight HAM/TSP patients after culture for 24 hours. Spontaneous degranulation/IFN- $\gamma$ expression in CD8 ${ }^{+} T$ cells of HAM/TSP patients was significantly inhibited by minocycline treatment $\left({ }^{*} p=0.0078\right.$; all by Wilcoxon matched-pairs signed rank test). Error bars represent SD. 
patients with HAM/TSP, we examined CD107a and IFN- $\gamma$ expression in $\mathrm{CD} 8^{+} \mathrm{T}$ cells of patients with $\mathrm{HAM} / \mathrm{TSP}$, who were subtyped as HLA-A*201, by stimulation with a known immunodominant HLA-A2binding HTLV-I Tax11-19 peptide [35]. As previously reported [36], cytotoxicity (CD107 expression) can be triggered at peptide concentrations 10- to 100 -fold less than those required for inflammatory cytokine (IFN- $\gamma$ ) production in primary virus-specific human $\mathrm{CD}^{+} \mathrm{T}$ cells. In $\mathrm{CD}^{+} \mathrm{T}$ cells of a patient with HAM/TSP, after stimulation with the low peptide concentration $(0.1 \mathrm{ng} /$ $\mathrm{ml}$ ) for 5 hours, the majority of responding cells degranulated, but produced little or no detectable IFN- $\gamma$ (Figure $5 \mathrm{~A}$ ). As the peptide concentration was increased, more cells exhibited dual effector functions of degranulation and IFN- $\gamma$ production (Figure $5 \mathrm{~A}$ ). Thus, $\mathrm{CD}^{+} \mathrm{T}$ cells exhibited inflammatory changes following cytotoxic responses depending on the quantity of antigen stimulation. Figure 5B shows representative dot plots of $\mathrm{CD} 107 \mathrm{a}$ and IFN- $\gamma$ expressions in $\mathrm{CD}^{+} \mathrm{T}$ cells of a HLA-A*201 ${ }^{+}$patient with HAM/TSP after the Tax11-19 stimulation with or without minocycline treatment. As the peptide concentration increased, more cells exhibited both degranulation and IFN- $\gamma$ production in $\mathrm{CD}^{+}$ $\mathrm{T}$ cells of a HAM/TSP patient (Figure 5B, upper dot plots). Interestingly, as the cells were treated with minocycline, both degranulation and IFN- $\gamma$ production were detected in Tax11-19-specific CD8 ${ }^{+} \mathrm{T}$ cells, but the frequency of CD107a $\mathrm{a}^{+} \mathrm{IFN}-\gamma^{+}$cell population did not increase in $\mathrm{CD}^{+} \mathrm{T}$ cells stimulated with increased Tax11-19 peptides (Figure 5B, lower dot plots). These results suggested that minocycline inhibited the activation of Tax-specific $\mathrm{CD}^{+} \mathrm{T}$ cells (Figure 5B, lower dot plots). In addition, IFN- $\gamma$ expression was reduced, but total CD107a expression did not change in Tax11-19-specific CD8 ${ }^{+} \mathrm{T}$ cells after minocycline treatment (Figure 5B, lower dot plots). Three HLA-A*201 ${ }^{+}$HAM/TSP patients showed that minocycline treatment inhibited $40 \%$ of $\mathrm{CD} 107 \mathrm{a}^{+} \mathrm{IFN}-\gamma^{+}$ expressions, but not total CD107a expressions, in $\mathrm{CD}^{+} \mathrm{T}$ cells after stimulation with Tax11-19 (Figure 5C). These results demonstrated that treatment with minocycline reduced the inflammatory responses (IFN- $\gamma$ expression), but retained anti-viral cytotoxic response (total CD107a expression) in Tax11-19-specific CD8 ${ }^{+} \mathrm{T}$ cells of HAM/ TSP patients.

\section{Minocycline down-regulated MHC class I expression on MPs of patients with HAM/TSP}

As $\mathrm{CD}^{+} \mathrm{T}$ cells are stimulated by antigenic peptides that are presented by MHC class I molecules expressed on the surface of antigen-presenting cells, we asked whether the effect of minocycline that modulates the inflammatory response in Tax-specific $\mathrm{CD} 8^{+} \mathrm{T}$ cells of patients with HAM/TSP might be associated with decreased capacity of antigen-presentation in MPs. To clarify the capacity of antigen-presentation in MPs, we examined MHC class I expression on MPs of patients with HAM/TSP after culture with or without minocycline treatment. Figure $6 \mathrm{~A}$ shows representative histograms of MHC class I expression on $\mathrm{CD}_{14}{ }^{+}$cells in a patient with HAM/TSP before and after culture for 5 and 18 hours. MHC class I expression on $\mathrm{CD}_{1} 4^{+}$cells of a patient with HAM/TSP gradually increased after culture (Figure 6A). After treatment with minocycline, $\mathrm{MHC}$ class I expression on $\mathrm{CD} 14^{+}$cells gradually decreased, compared to those on $\mathrm{CD} 14^{+}$cells without minocycline (Figure 6A). Group analysis including three patients with HAM/TSP showed that mean fluorescent intensities of MHC class I expression on CD14 ${ }^{+}$cells were significantly inhibited by treatment with minocycline after 18 hours culture (Figure 6B). These results demonstrated that minocycline down-modulated MHC class I expression on activated HAM/TSP MPs, suggesting that the inflammatory response of $\mathrm{CD}^{+} \mathrm{T}$ cells in patients with HAM/TSP was suppressed through down-regulation of MP activation by minocycline.

\section{Discussion}

MPs play pivotal roles in antigen capture and presentation, pathogen and tissue debris clearance, and cellular secretory functions. However, activated MPs can infiltrate through the blood brain barrier and contribute to the CNS inflammation by secreting various inflammatory cytokines and growth-inhibiting proteins. In HAM/TSP, MPs are reservoirs of HTLV-I, induce proinflammatory cytokines and excessive antigen-specific $\mathrm{T}$ cell responses, and can also infiltrate the CNS. In our study, we analyzed CD14 ${ }^{+}$ cell subpopulation in PBMCs of patients with HAM/TSP and demonstrated that $\mathrm{CD} 14^{\text {low }} \mathrm{CD} 16^{+}$subset of patients with HAM/TSP showed significantly higher $\mathrm{CX}_{3} \mathrm{CR} 1$ and HLA-DR expression, compared to NDs and ACs. Since it has been reported that $\mathrm{CX}_{3} \mathrm{CR} 1$ expression is regulated by IL-2 and IL-15 [37], activated T cells expressing these cytokines might affect $\mathrm{CX}_{3} \mathrm{CR} 1$ expression on monocytes in patients with HAM/TSP $[19,38,39]$. In mice, GR1 ${ }^{-}$ $\mathrm{CX}_{3} \mathrm{CR} 1^{\text {high }}$ monocytes (homolog of human $\mathrm{CD} 16^{+}$monocytes) patrol vascular endothelium by mechanisms involving LFA- 1 and $\mathrm{CX}_{3} \mathrm{CR} 1$ and are rapidly recruited into inflamed tissues, such as spleen, gut, lung and brain, where they differentiate into macrophage $[23,40]$. In humans, $\mathrm{CD} 16^{+}$monocytes that have the potential to migrate preferentially in response to fractalkine, a ligand of $\mathrm{CX}_{3} \mathrm{CR} 1$, have more $\mathrm{Fc}$ receptor mediated phagocytosis function and are at a more advanced stage of differentiation to macrophage and dendritic cell [41-43]. These findings suggest that $\mathrm{CD} 14^{\text {low }} \mathrm{CD} 16^{+}$and $\mathrm{CD} 14^{+} \mathrm{CD} 16^{-}$cells are recruited into different anatomic sites under constitutive or inflammatory conditions and play distinct functional roles in immunity and disease pathogenesis. 
A

Tax11-19 peptide

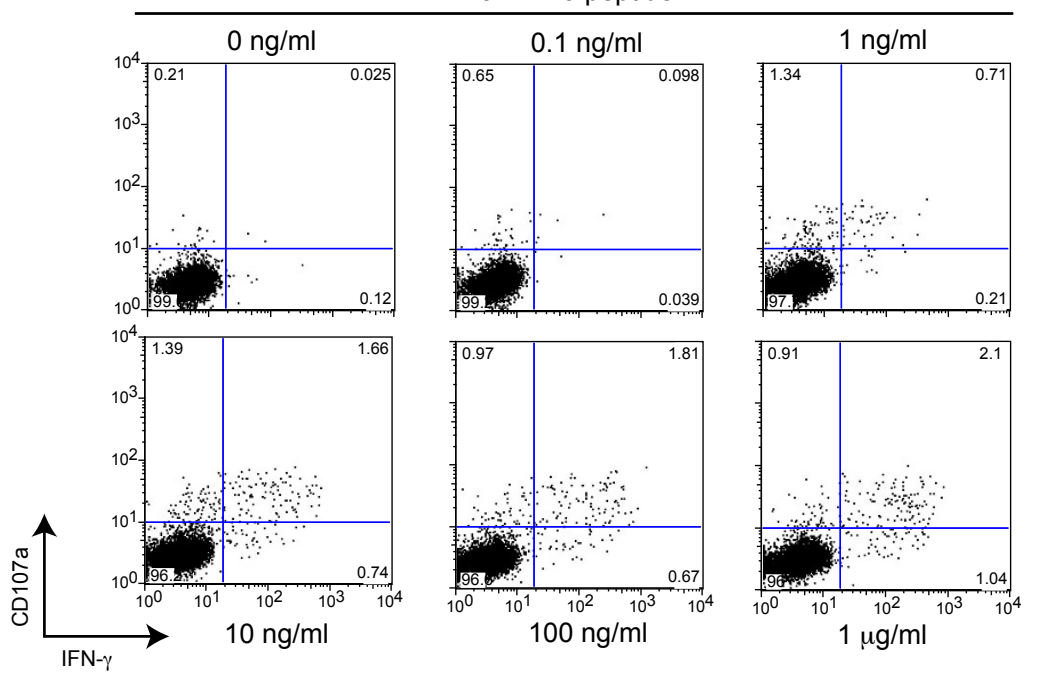

B

Tax11-19 peptide
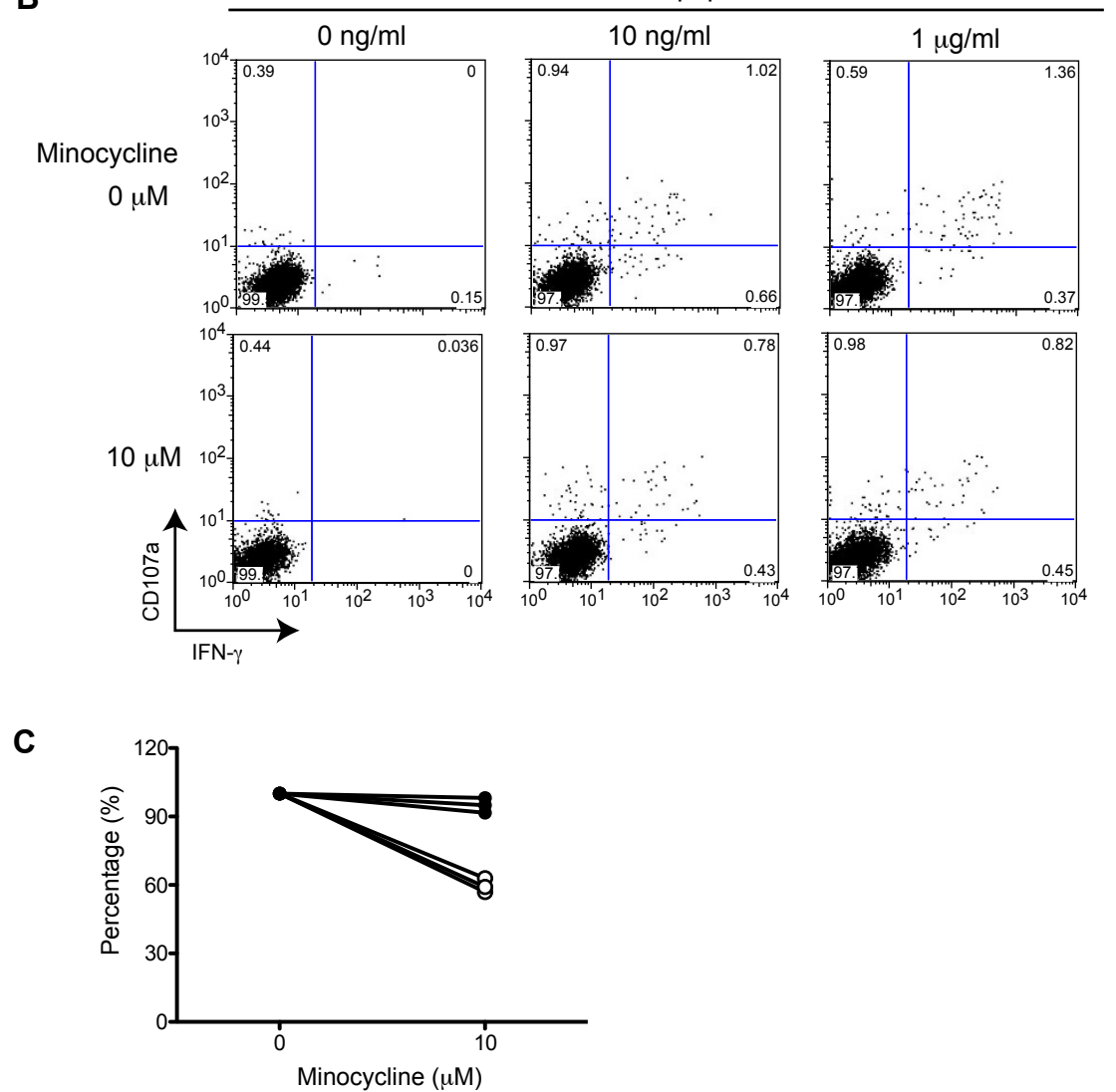

Figure 5 Minocycline inhibited Tax11-19-specific IFN- $\gamma$ expression in CD8 ${ }^{+}$T cells of patients with HAM/TSP. (A) Representative dot plots of CD107 and IFN- $\gamma$ expression in CD8 ${ }^{+}$T cells of a HLA-A*201+ HAM/TSP patients, stimulated with Tax11-19 peptides. PBMCs were stimulated with Tax 11-19 peptide at concentration of $0,0.1,1,10,100 \mathrm{ng} / \mathrm{ml}$, and $1 \mathrm{\mu g} / \mathrm{ml}$ for 5 hours. (B) Representative dot plots of Tax11-19 specific CD107 and IFN- $\gamma$ expression in CD8 ${ }^{+} \mathrm{T}$ cells of a HAM/TSP patient after treatment with or without $10 \mu \mathrm{M}$ of minocycline. PBMCs were stimulated with Tax 11-19 peptide at concentration of $0,10 \mathrm{ng} / \mathrm{ml}$ and $1 \mu \mathrm{g} / \mathrm{ml}$ for 5 hours. (C) Inhibitory effects of minocycline on IFN- $\gamma$ expression, but not degranulation, in CD8 ${ }^{+} \mathrm{T}$ cells of HAM/TSP patients after stimulation with $1 \mu \mathrm{g} / \mathrm{ml}$ of Tax 11-19 peptides. The amounts of CD107a ${ }^{+}$(closed circles) and $\mathrm{CD} 107 \mathrm{a}^{+} \mathrm{IFN}-\gamma^{+}$(opened circles) cells in $\mathrm{CD} 8^{+} \mathrm{T}$ cells cultured without minocycline were normalized to $100 \%$, and then, those in CD8 ${ }^{+} \mathrm{T}$ cells cultured with minocycline were calculated. The graph was prepared from data obtained from three HLA-A*201 ${ }^{+}$HAM/TSP patients. Tax11-19-specific IFN- $\gamma$ expression, but not degranulation, in CD8 ${ }^{+}$T cells of HAM/TSP patients was inhibited $40 \%$ by minocycline treatment. 
A

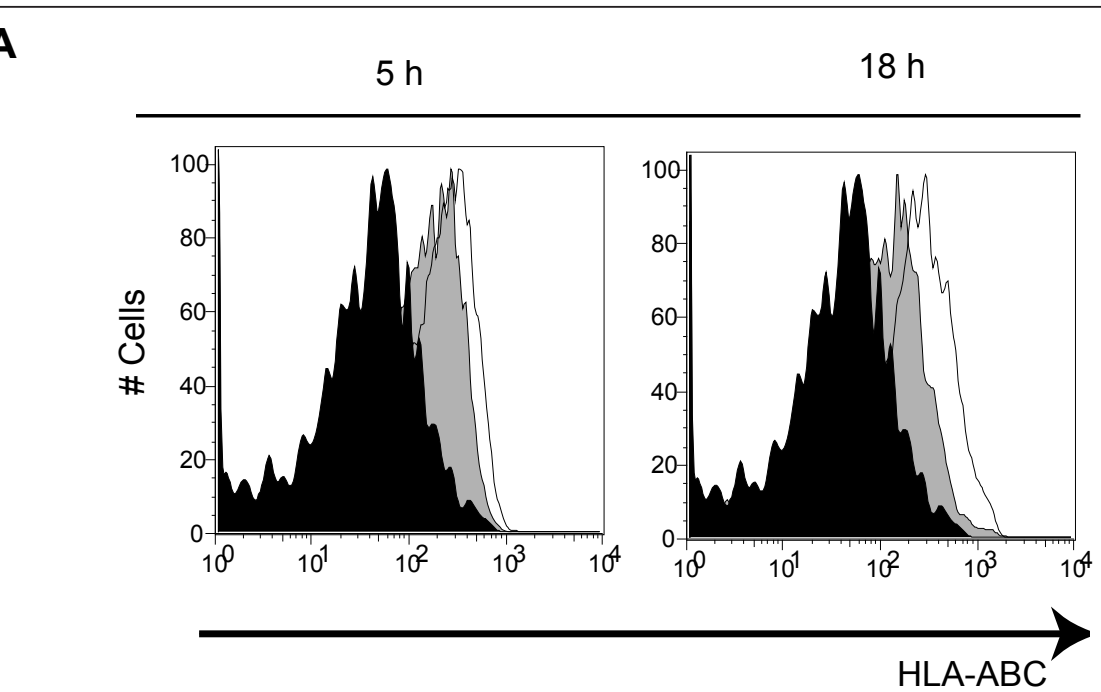

B

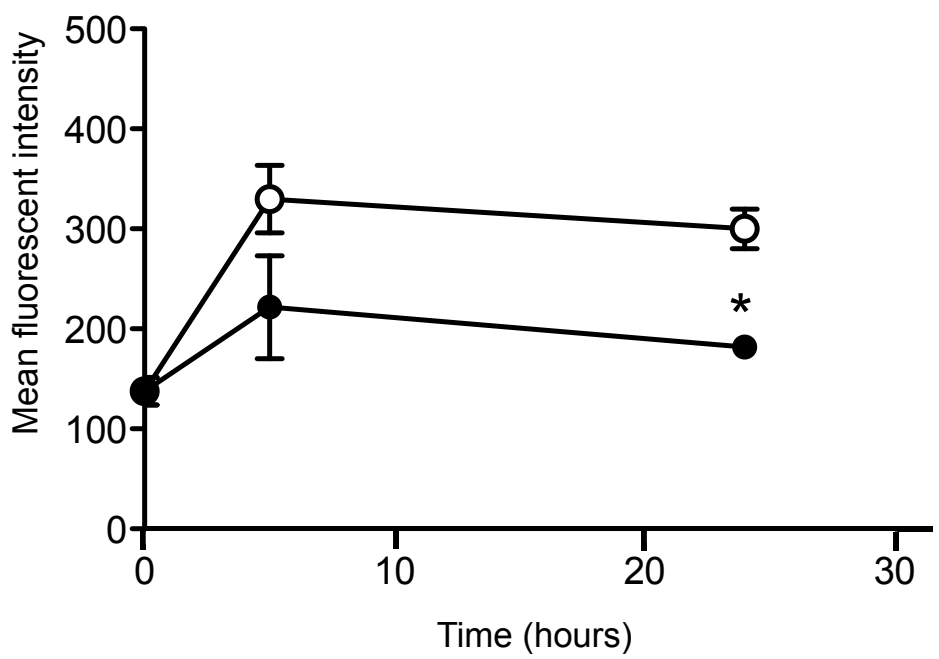

Figure 6 Minocycline downregulated HLA-ABC expressions in CD14 ${ }^{+}$cells of patients with HAM/TSP. (A) Representative histograms of HLA-ABC expression on CD $14^{+}$cells of a HAM/TSP patient. Staining on CD14 $4^{+}$cells before culture (closed histogram) and after culture for 5 hours and 18 hours, with minocycline (grayed histogram) and without minocycline (opened histogram), were shown. (B) Comparison of HLA$\mathrm{ABC}$ expression in $\mathrm{CD} 14^{+}$cells of HAM/TSP patients after 18 hours culture with minocycline (closed circle) or without minocycline (opened circle). The mean fluorescent intensities of $\mathrm{MHC}$ class I expression on $\mathrm{CD} 14^{+}$cells were significantly inhibited by treatment with minocycline at 18 hours culture $\left({ }^{*} p=0.0382\right)$. Error bars represent SD.

Fractalkine is expressed on activated endothelial cells [44], neuron [45], apoptotic cells [46], and brain with inflammation [47]. Therefore, HTLV-I-activated or infected cells might induce fractalkine expression at the site of inflammation such as the spinal cord to recruit and adhere $\mathrm{CX}_{3} \mathrm{CR}^{+}$cells. The hypothesis was supported by the accumulation of $\mathrm{CX}_{3} \mathrm{CR} 1^{+}$cells immunohistochemically detected in the meninges and parenchyma of HAM/TSP spinal cords as well as around blood vessels (Figure 1D). The $\mathrm{CX}_{3} \mathrm{CR} 1^{+}$cells were $\mathrm{CD} 68^{+}$and also morphologically consistent with MPs. Therefore, these results suggested that $\mathrm{CX}_{3} \mathrm{CR}^{+}{ }^{+} \mathrm{MPs}$ could accumulate in spinal cords of patients with HAM/TSP. Moreover, the increase of degranulation and IFN- $\gamma$ expression in $\mathrm{CD}^{+} \mathrm{T}$ cells were significantly correlated with the increase of $\mathrm{CX}_{3} \mathrm{CR} 1$ and HLADR expression in $\mathrm{CD} 14^{\text {low }}{ }^{\mathrm{CD}} 16^{+}$subset of HTLV-Iinfected patients. These results support the hypothesis that strong correlation between $\mathrm{CD} 8^{+} \mathrm{T}$ cell activation and MP activation contribute to the pathogenesis of HAM/TSP. These differential changes in peripheral MP 
subpopulations in vivo may also be associated with the infiltration of MPs into the CNS and $\mathrm{CD}^{+} \mathrm{T}$ cell activation in patients with neurologic inflammatory disease.

MP activation in patients with HAM/TSP was also suggested by TNF- $\alpha$ and IL- $1 \beta$ expression in CD14 ${ }^{+}$ cells. Expression of IL-1 $\beta$ and TNF- $\alpha$ was detected in perivascular infiltrating macrophages and microglia in the spinal cords of patients with HAM/TSP and in infiltrating macrophage in the muscle of patients with HTLV-I-related myositis $[27,48]$. Thus, the proinflammatory cytokine expression in peripheral MPs might be related to the infiltration of MPs into the inflammatory site of patients with HTLV-I-related diseases. Moreover, CD14 ${ }^{+}$cells accelerated HTLV-I Tax expression of autologous $\mathrm{CD} 4^{+} \mathrm{CD} 25^{+} \mathrm{T}$ cells in patients with HAM/TSP, which was dependent on cell-cell contact. In patients with HAM/TSP, high HTLV-I Tax expression is mainly detected in $\mathrm{CD}_{4}^{+} \mathrm{T}$ cells after ex vivo culture, but dendritic cells and CD14 ${ }^{+}$cells can also express HTLV-I Tax, consistent with the observation that HTLV-I infects dendritic cells to effectively transfer cell-free virus to $\mathrm{CD}^{+} \mathrm{T}$ cells $[18,19]$. In HIV, human CD16 ${ }^{+}$ monocytes have been shown to be more susceptible to infection than $\mathrm{CD}^{-} 6^{-}$monocytes, to preferentially harbor the virus over the long-term, and to promote high levels of HIV replication upon differentiation into macrophages and interaction with activated $\mathrm{T}$ cells $[30,49]$. Therefore, HTLV-I infected and activated MP might likewise contribute to $\mathrm{T}$ cell activation and virus dissemination in HTLV-I associated disease.

Minocycline is a well known as inhibitor of MP activation and has been reported to have beneficial effects on inflammation, microglial activation, matrix metalloproteinases, nitric oxide production, and apoptotic cell death [29]. Furthermore, minocycline has been suggested to have neuroprotective effects in human as well as in animal models of a number of neurologic diseases including stroke, multiple sclerosis, and Parkinson's disease [29]. In our study, minocycline treatment significantly inhibited proinflammatory cytokine expression (TNF- $\alpha$ and IL-1 $\beta$ ) in $\mathrm{CD} 14^{+}$cells of patients with HAM/TSP, while TNF- $\alpha$ expressions in $\mathrm{CD} 4^{+} \mathrm{T}$ cells of patients with HAM/TSP did not change. These results suggest that the effects of minocycline may act through inhibition of MP activation rather than HTLV-associated T cell activation. Unexpectedly, minocycline treatment also effectively inhibited spontaneous lymphoproliferation and IFN- $\gamma$ expression of $\mathrm{CD}^{+} \mathrm{T}$ cells, which are well-described observations of $\mathrm{T}$ cell activation in patients with HAM/TSP. While these $\mathrm{T}$ cell responses have been reported to be due to IL-2/IL2 receptor and IL-15/IL-15 receptor autocrine loop following expression of HTLV-I Tax in T cells [32,38], a number of studies have demonstrated that non- $\mathrm{T}$ cells and $\mathrm{CD} 14^{+}$cells can also play a stimulatory role in
HTLV-I-associated T cell activation $[5,19,38]$. Therefore, our results support the view that $\mathrm{T}$ cell responses in patients with HAM/TSP are due, in part, to the activation of MPs.

Inhibition of MPs resulted in the suppression of $\mathrm{CD}^{+} \mathrm{T}$ cell dysregulation (degranulation and IFN $-\gamma$ expression). Elevated IFN $-\gamma$ expression is an important immunological marker in the pathogenesis of HAM/TSP [50], and CD8 ${ }^{+}$ $\mathrm{T}$ cell dysregulation was mediated by various factors, including virus infection, enhanced IL-2/IL-15, and expression of cellular molecules [19,51-54]. Unexpectedly, minocycline inhibited spontaneous degranulation/IFN- $\gamma$ expression in $\mathrm{CD}^{+} \mathrm{T}$ cells of HAM/TSP patients as well as HTLV-I Tax11-19-specific CD8 ${ }^{+} \mathrm{T}$ cell responses. Antiviral $\mathrm{CD} 8^{+} \mathrm{T}$ cells can elaborate at least two effector functions, cytotoxicity and inflammatory cytokine production, which are determined primarily by antigen concentration [36]. Interestingly, minocycline treatment suppressed inflammatory IFN- $\gamma$ production, but not total cytotoxicity (CD107a expression) in Tax-specific CD8 ${ }^{+} \mathrm{T}$ cells of patients with HAM/TSP. Moreover, after the treatment with minocycline, MHC class I expression on $\mathrm{CD} 14^{+}$cells of patients with HAM/TSP was gradually suppressed in cultured cells, compared to untreated MPs. These results suggested that the activation of $\mathrm{CD}^{+} \mathrm{T}$ cells was inhibited through MHC class I downregulation on $\mathrm{CD} 14^{+}$cells after minocycline treatment. This may be one mechanism involved in the reduction of $\mathrm{CD}^{+} \mathrm{T}$ cell inflammatory IFN- $\gamma$ production in the presence of minocycline. Moreover, minocycline significantly inhibited spontaneous degranulation/IFN- $\gamma$ expression in $\mathrm{CD}^{+}{ }^{+} \mathrm{T}$ cells of HAM/ TSP patients. As previously reported, the spontaneous degranulation/IFN- $\gamma$ expression in $\mathrm{CD}^{+} \mathrm{T}$ cells of HAM/ TSP patients was mediated by various factor(s) $[19,52]$. To evaluate regulatory effects of $\mathrm{CD} 8^{+} \mathrm{T}$ cell by minocycline, further analysis would be needed. In addition, even though minocycline down-modulates the capacity of antigen-presenting cells to trigger $\mathrm{CD}^{+} \mathrm{T}$ cell effector responses, the cytotoxic function of Tax-specific $\mathrm{CD} 8^{+} \mathrm{T}$ cells might be still maintained and continue to provide control of virus-infected cells. This may have a positive clinical consequence for use of minocycline in treatment of HTLV-Iassociated disease.

\section{Conclusions}

Collectively, these results suggest that minocycline does not only inhibit the activation of MPs of patients with HAM/TSP, but also HTLV-I-associated T cell activation such as lymphoproliferation and inflammatory cytokine production of $\mathrm{CD}^{+} \mathrm{T}$ cells through the downregulation of MP function. Thus, the inhibition of HTLV-I-infected or activated MPs may be of clinical use in the treatment of patients with HTLV-I-associated neurological disease. 


\section{Methods \\ Patient samples}

Blood samples were obtained from twelve patients with HAM/TSP (HAM\#1-12), six HTLV-I-seropositive asymptomatic carriers (AC\#1-6), and ten HTLV-I-seronegative healthy donors (ND\#1-10). Diagnosis of HAM/TSP was based on WHO diagnostic criteria. Three patients with HAM/TSP were HLA-A*201+. PBMCs were isolated by Ficoll-Hypaque (Lonza Walkersville, Walkersville, MD) centrifugation. The PBMCs obtained from HTLV-Iinfected patients or ND were cryopreserved in liquid nitrogen until use. Informed consent was obtained from each subject. The study was reviewed and approved by the National Institute of Neurological Disorders and Stroke (NINDS) Institutional Review Board. Informed consent was obtained in accordance with the Declaration of Helsinki.

\section{Antibodies and reagents}

For flow cytometry, antibodies for human CD3, CD4, CD8, CD14, CD16, CD28, CD49d, CD107a, IFN- $\gamma$, TNF$\alpha$, and HLA-DR (all from BD Biosciences, San Jose, CA), $\mathrm{CX}_{3} \mathrm{CR} 1$ (Medical and Biological laboratories, Nagoya, Japan), HLA-ABC (AbD Serotec, Oxford, UK), and antiTax monoclonal antibody (Lt-4) were used. For immunohistochemistry, rabbit polyclonal anti-human $\mathrm{CX}_{3} \mathrm{CR} 1$ (abcam, Cambridge, MA) was used as primary antibody. Minocycline was purchased from Sigma (St. Louis, MO).

\section{Cell culture}

PBMCs of NDs or patients with HAM/TSP were suspended at $1 \times 10^{6}$ cells $/ \mathrm{mL}$ in RPMI media (RPMI 1640 supplemented with $10 \%$ heat-inactivated fetal bovine serum, $100 \mathrm{U} / \mathrm{mL}$ penicillin, $100 \mu \mathrm{g} / \mathrm{mL}$ streptomycin sulfate, and $2 \mathrm{mM}$ L-glutamine), and cultured for 24 hours either with or without minocycline in 24 well plate in $5 \%$ $\mathrm{CO}_{2}$ incubator at $37^{\circ} \mathrm{C}$. The culture supernatants were collected, centrifuged at $2000 \mathrm{~g}$ for $10 \mathrm{~min}$ to remove cellular debris and stored at $-80^{\circ} \mathrm{C}$ until use. The cultured cells were collected for immunofluorescence staining or stored at $-80^{\circ} \mathrm{C}$ until use. For immunofluorescence staining of MHC class I on MPs, PBMCs were collected after culture for 5 hours or 18 hours.

To examine Tax expression in $\mathrm{CD}^{+} \mathrm{T}$ cells cocultured with or without $\mathrm{CD} 14^{+}$cells, $\mathrm{CD} 4^{+} \mathrm{CD} 25^{+} \mathrm{T}$ cells or $\mathrm{CD} 4$ ${ }^{+} \mathrm{CD} 25^{-} \mathrm{T}$ cells and $\mathrm{CD} 14^{+}$cells were magnetically isolated from PBMCs of HTLV-I-infected patients by $\mathrm{CD} 4^{+} \mathrm{CD} 25^{+}$ Regulatory $\mathrm{T}$ cell Isolation Kit and CD14 MicroBeads (both from Miltenyi Biotec, Bergisch Gladbach, Germany), respectively, according to the manufacture's instruction, and $2 \times 10^{5}$ cells of each $\mathrm{CD} 4^{+} \mathrm{T}$ cells were cocultured with or without the same amount of autologous CD14 ${ }^{+}$ cells for 18 hours in 48 well plate in $5 \% \mathrm{CO}_{2}$ incubator at $37^{\circ} \mathrm{C}$.
ELISA

IL-1 $\beta$ was detected in the PBMC culture supernatants of NDs and patients with HAM/TSP using Human IL-1 $\beta$ Quantikine ELISA ( $R$ \& D systems), according to the manufacturer's instructions

\section{CD107a mobilization assay}

CD107a mobilization assay was performed as previously described [19]. To detect spontaneous degranulation and IFN- $\gamma$ expression in $\mathrm{CD}^{+} \mathrm{T}$ cells, PBMCs of patients with HAM/TSP were cultured for 24 hours. To detect Tax11-19 specific responses, PBMCs were stimulated with an appropriate concentration of HTLV-I Tax11-19 LLFGYPVYV and $1 \mu \mathrm{g} / \mathrm{mL}$ each of CD28 and CD49d for 5 hours. In treatment of minocycline, appropriate minocycline was added into the culture. Conjugated CD107a antibody, $0.7 \mu \mathrm{L} / \mathrm{mL}$ of GoldiStop ${ }^{\mathrm{TM}}$ (BD Biosciences), and $1 \mu \mathrm{g} / \mathrm{mL}$ of brefeldin A (Sigma) were added into the culture for 5 hours before the time point for detection.

\section{Flow cytometry}

For analysis of peripheral blood monocyte populations, patients' PBMCs were stained with CD3, CD4, CD8, CD14, CD16, HLA-DR and $\mathrm{CX}_{3} \mathrm{CR} 1$. Expression of CD107a, IFN- $\gamma$, TNF- $\alpha$ and intracellular Tax in the cultured or uncultured PBMCs was examined by flow cytometoric analysis. First, PBMCs were surface-stained with specific antibodies. After fixation and permeabilization with Fixation/Permeabilization solution (BD Biosciences) according to the manufacturer's instructions, the cells were intracellularly stained with anti-IFN- $\gamma$, anti-TNF- $\alpha$ or anti-Tax for each experiment. Flow cytometric analysis was performed using a FACSCalibur flow cytometer (BD Biosciences) or LSR II (BD Biosciences). The data were analyzed using FlowJo software (Tree Star, San Carlos, CA).

\section{Lymphoproliferation assay}

Lymphoproliferation assay was performed as previously described [55]. PBMCs were suspended in RPMI medium supplemented with $5 \%$ human $A B$ serum, $100 \mathrm{U} /$ $\mathrm{mL}$ penicillin, $100 \mu \mathrm{g} / \mathrm{mL}$ streptomycin sulfate, and 2 $\mathrm{mM}$ L-glutamine, and plated in triplicate on a round bottom 96-well plate at a concentration of $3 \times 10^{5}$ cells/ well with or without minocycline. The cells were cultured in $5 \% \mathrm{CO}_{2}$ incubator at $37^{\circ} \mathrm{C}$, and pulsed after 3 to 5 days of culture for $4 \mathrm{~h}$ with $1 \mu \mathrm{Ci}\left[{ }^{3} \mathrm{H}\right]$ thymidine. The average cpm from each of the wells was plotted.

\section{Immunohistochemistry}

Spinal cord tissues from a patient with HAM/TSP were fixed with buffered formalin and embedded in paraffin wax. Microtome sections were cut $10 \mu \mathrm{m}$ thick. Sections 
were deparaffinized with xylene, rehydrated and immersed in Target Retrieval Solution, pH6.0, (Dako, Carpinteria, CA) at $121^{\circ} \mathrm{C}$ for $10 \mathrm{~min}$. After blocking of endogenous peroxide with 3\% hydrogen peroxide for 10 min, the sections were incubated with a rabbit anti$\mathrm{CX}_{3} \mathrm{CR} 1$ antibody $(1 \mu \mathrm{g} / \mathrm{ml})$ for one hour at room temperature. Reactivity was visualized with diaminobenzidine (DAB) using Envision ${ }^{\mathrm{TM}_{+}}$system (Dako), followed by counterstaining with hematoxylin. The stained sections were visualized with Zeiss 200M Axiovert inverted microscope (Carl Zeiss MicroImaging Inc, Thornwood, NY). The image data of each section were created using Volocity imaging analysis software (Improvision, Waltham, MA).

\section{Statistical analysis}

Mann-Whitney test and Wilcoxon matched-pairs signed rank test were used for comparison between groups. Simple linear regression analysis was used for explaining a relationship between groups, respectively. All statistical analysis was performed using Prism (GraphPad software).

\section{Acknowledgements}

This research was supported by the Intramural Research Program of the NINDS, NIH.

\section{Author details \\ 'Viral Immunology Section, Neuroimmunology Branch, National Institute of Neurological Disorders and Stroke, National Institutes of Health, Bethesda, Maryland 20892 USA. ${ }^{2}$ Department of Neurology and Geriatrics, Graduate School of Medical and Dental Sciences, Kagoshima University, Kagoshima 890-8544 Japan. ${ }^{3}$ Department of Immunology, Graduate School and Faculty of Medicine, University of the Ryukyus, Okinawa 903-0215 Japan. ${ }^{4}$ Department of Neurology, Virginia Commonwealth University School of Medicine, Richmond, Virginia 23298 USA.}

\section{Authors' contributions}

YE-A designed the research, performed most of the experiments, analyzed results, made the figures and wrote the manuscript; EM analyzed immunohistochemical image, analyzed results, made the figures and wrote the manuscript; UO coordinated clinical work, analyzed results and wrote the manuscript; YT contributed reagents for analysis. SJ designed the research, analyzed results and wrote the manuscript. All authors read and approved the final manuscript.

\section{Competing interests}

The authors declare that they have no competing interests.

Received: 17 November 2011 Accepted: 15 February 2012

Published: 15 February 2012

\section{References}

1. Verdonck K, Gonzalez E, Van Dooren S, Vandamme AM, Vanham G, Gotuzzo E: Human T-lymphotropic virus 1: recent knowledge about an ancient infection. The Lancet infectious diseases 2007, 7:266-281.

2. Poiesz BJ, Ruscetti FW, Gazdar AF, Bunn PA, Minna JD, Gallo RC: Detection and isolation of type $C$ retrovirus particles from fresh and cultured lymphocytes of a patient with cutaneous T-cell lymphoma. Proceedings of the National Academy of Sciences of the United States of America 1980, 77:7415-7419.
3. Gessain A, Barin F, Vernant JC, Gout O, Maurs L, Calender A, de The G: Antibodies to human T-lymphotropic virus type-I in patients with tropical spastic paraparesis. Lancet 1985, 2:407-410.

4. Osame M, Usuku K, Izumo S, ljichi N, Amitani H, Igata A, Matsumoto M, Tara M: HTLV-I associated myelopathy, a new clinical entity. Lancet 1986, 1:1031-1032

5. Itoyama Y, Minato S, Kira J, Goto I, Sato H, Okochi K, Yamamoto N: Spontaneous proliferation of peripheral blood lymphocytes increased in patients with HTLV-I-associated myelopathy. Neurology 1988, 38:1302-1307.

6. Jacobson S, Shida H, McFarlin DE, Fauci AS, Koenig S: Circulating CD8+ cytotoxic T lymphocytes specific for HTLV-I pX in patients with HTLV-I associated neurological disease. Nature 1990, 348:245-248.

7. Kubota R, Kawanishi T, Matsubara H, Manns A, Jacobson S: HTLV-I specific IFN-gamma+ CD8+ lymphocytes correlate with the proviral load in peripheral blood of infected individuals. J Neuroimmunol 2000, 102:208-215.

8. Hanon E, Goon P, Taylor GP, Hasegawa H, Tanaka Y, Weber JN, Bangham CR: High production of interferon gamma but not interleukin-2 by human T-lymphotropic virus type l-infected peripheral blood mononuclear cells. Blood 2001, 98:721-726.

9. Yamano $Y$, Nagai M, Brennan M, Mora CA, Soldan SS, Tomaru U, Takenouchi N, Izumo S, Osame M, Jacobson S: Correlation of human T-cell lymphotropic virus type 1 (HTLV-1) mRNA with proviral DNA load, virusspecific CD8(+) T cells, and disease severity in HTLV-1-associated myelopathy (HAM/TSP). Blood 2002, 99:88-94.

10. Hanon E, Hall S, Taylor GP, Saito M, Davis R, Tanaka Y, Usuku K, Osame M, Weber JN, Bangham CR: Abundant tax protein expression in CD4+ T cells infected with human T-cell lymphotropic virus type I (HTLV-I) is prevented by cytotoxic T lymphocytes. Blood 2000, 95:1386-1392.

11. Asquith B, Zhang Y, Mosley AJ, de Lara CM, Wallace DL, Worth A, Kaftantzi L, Meekings K, Griffin GE, Tanaka Y, Tough DF, Beverley PC, Taylor GP, Macallan DC, Bangham CR: In vivo T lymphocyte dynamics in humans and the impact of human T-lymphotropic virus 1 infection. Proceedings of the National Academy of Sciences of the United States of America 2007, 104:8035-8040.

12. Nagai M, Yamano Y, Brennan MB, Mora CA, Jacobson S: Increased HTLV-I proviral load and preferential expansion of HTLV-I Tax-specific CD8+ T cells in cerebrospinal fluid from patients with HAM/TSP. Annals of neurology 2001, 50:807-812.

13. Koralnik IJ, Lemp JF Jr, Gallo RC, Franchini G: In vitro infection of human macrophages by human T-cell leukemia/lymphotropic virus type I (HTLV-I). AIDS research and human retroviruses 1992, 8:1845-1849.

14. Macatonia SE, Cruickshank JK, Rudge P, Knight SC: Dendritic cells from patients with tropical spastic paraparesis are infected with HTLV-1 and stimulate autologous lymphocyte proliferation. AIDS research and human retroviruses 1992, 8:1699-1706.

15. Hoffman PM, Dhib-Jalbut S, Mikovits JA, Robbins DS, Wolf AL, Bergey GK, Lohrey NC, Weislow OS, Ruscetti FW: Human T-cell leukemia virus type I infection of monocytes and microglial cells in primary human cultures. Proceedings of the National Academy of Sciences of the United States of America 1992, 89:11784-11788.

16. Koyanagi Y, Itoyama Y, Nakamura N, Takamatsu K, Kira J, Iwamasa T, Goto I, Yamamoto N: In vivo infection of human T-cell leukemia virus type I in non-T cells. Virology 1993, 196:25-33.

17. Makino M, Shimokubo S, Wakamatsu SI, Izumo S, Baba M: The role of human T-lymphotropic virus type 1 (HTLV-1)-infected dendritic cells in the development of HTLV-1-associated myelopathy/tropical spastic paraparesis. Journal of virology 1999, 73:4575-4581.

18. Jones KS, Petrow-Sadowski C, Huang YK, Bertolette DC, Ruscetti FW: Cellfree HTLV-1 infects dendritic cells leading to transmission and transformation of CD4(+) T cells. Nature medicine 2008, 14:429-436.

19. Enose-Akahata Y, Oh U, Grant C, Jacobson S: Retrovirally induced CTL degranulation mediated by IL-15 expression and infection of mononuclear phagocytes in patients with HTLV-I-associated neurologic disease. Blood 2008, 112:2400-2410.

20. Umehara F, Izumo S, Nakagawa M, Ronquillo AT, Takahashi K, Matsumuro K, Sato E, Osame M: Immunocytochemical analysis of the cellular infiltrate in the spinal cord lesions in HTLV-I-associated myelopathy. Journal of neuropathology and experimental neurology 1993, 52:424-430. 
21. Izumo S, Umehara F, Kashio N, Kubota R, Sato E, Osame M: Neuropathology of HTLV-1-associated myelopathy (HAM/TSP). Leukemia 1997, 11(Suppl 3):82-84.

22. Mellman I, Steinman RM: Dendritic cells: specialized and regulated antigen processing machines. Cell 2001, 106:255-258.

23. Geissmann F, Jung S, Littman DR: Blood monocytes consist of two principal subsets with distinct migratory properties. Immunity 2003, 19:71-82.

24. Ziegler-Heitbrock L: The CD14+ CD16+ blood monocytes: their role in infection and inflammation. Journal of leukocyte biology 2007, 81:584-592.

25. Kadiu I, Glanzer JG, Kipnis J, Gendelman HE, Thomas MP: Mononuclear phagocytes in the pathogenesis of neurodegenerative diseases. Neurotoxicity research 2005, 8:25-50.

26. Tendler CL, Greenberg SJ, Burton JD, Danielpour D, Kim SJ, Blattner WA, Manns A, Waldmann TA: Cytokine induction in HTLV-I associated myelopathy and adult T-cell leukemia: alternate molecular mechanisms underlying retroviral pathogenesis. Journal of cellular biochemistry 1991, 46:302-311.

27. Umehara F, Izumo S, Ronquillo AT, Matsumuro K, Sato E, Osame M: Cytokine expression in the spinal cord lesions in HTLV-I-associated myelopathy. Journal of neuropathology and experimental neurology 1994 53:72-77.

28. Tsukada J, Misago M, Serino Y, Ogawa R, Murakami S, Nakanishi M, Tonai S, Kominato Y, Morimoto I, Auron PE, Eto S: Human T-cell leukemia virus type I Tax transactivates the promoter of human prointerleukin-1beta gene through association with two transcription factors, nuclear factorinterleukin-6 and Spi-1. Blood 1997, 90:3142-3153.

29. Zemke D, Majid A: The potential of minocycline for neuroprotection in human neurologic disease. Clinical neuropharmacology 2004, 27:293-298.

30. Ancuta P, Kunstman KJ, Autissier P, Zaman T, Stone D, Wolinsky SM, Gabuzda D: CD16+ monocytes exposed to HIV promote highly efficient viral replication upon differentiation into macrophages and interaction with T cells. Virology 2006, 344:267-276.

31. Coleman CM, Wu L: HIV interactions with monocytes and dendritic cells: viral latency and reservoirs. Retrovirology 2009, 6:51.

32. Tendler CL, Greenberg SJ, Blattner WA, Manns A, Murphy E, Fleisher T, Hanchard B, Morgan O, Burton JD, Nelson DL, et al: Transactivation of interleukin 2 and its receptor induces immune activation in human Tcell lymphotropic virus type l-associated myelopathy: pathogenic implications and a rationale for immunotherapy. Proceedings of the National Academy of Sciences of the United States of America 1990, 87:5218-5222.

33. Azimi N, Nagai M, Jacobson S, Waldmann TA: IL-15 plays a major role in the persistence of Tax-specific CD8 cells in HAM/TSP patients. Proceedings of the National Academy of Sciences of the United States of America 2001, 98:14559-14564.

34. Chen J, Petrus M, Bryant BR, Phuc Nguyen V, Stamer M, Goldman CK, Bamford R, Morris JC, Janik JE, Waldmann TA: Induction of the IL-9 gene by HTLV-I Tax stimulates the spontaneous proliferation of primary adult T-cell leukemia cells by a paracrine mechanism. Blood 2008, 111:5163-5172.

35. Koenig S, Woods RM, Brewah YA, Newell AJ, Jones GM, Boone E, Adelsberger JW, Baseler MW, Robinson SM, Jacobson S: Characterization of MHC class I restricted cytotoxic T cell responses to tax in HTLV-1 infected patients with neurologic disease. J Immunol 1993, 151:3874-3883.

36. Betts MR, Price DA, Brenchley JM, Lore K, Guenaga FJ, Smed-Sorensen A, Ambrozak DR, Migueles SA, Connors M, Roederer M, Douek DC, Koup RA: The functional profile of primary human antiviral CD8+ T cell effector activity is dictated by cognate peptide concentration. J Immunol 2004, 172:6407-6417

37. Barlic J, Sechler JM, Murphy PM: IL-15 and IL-2 oppositely regulate expression of the chemokine receptor CX3CR1. Blood 2003, 102:3494-3503.

38. Azimi N, Jacobson S, Leist T, Waldmann TA: Involvement of IL-15 in the pathogenesis of human $\mathrm{T}$ lymphotropic virus type I-associated myelopathy/tropical spastic paraparesis: implications for therapy with a monoclonal antibody directed to the IL-2/15R beta receptor. J Immunol 1999, 163:4064-4072.

39. Goon PK, Igakura T, Hanon E, Mosley AJ, Asquith B, Gould KG, Taylor GP, Weber JN, Bangham CR: High circulating frequencies of tumor necrosis factor alpha- and interleukin-2-secreting human T-lymphotropic virus type 1 (HTLV-1)-specific CD4+ T cells in patients with HTLV-1-associated neurological disease. Journal of virology 2003, 77:9716-9722.

40. Auffray C, Fogg D, Garfa M, Elain G, Join-Lambert O, Kayal S, Sarnacki S, Cumano A, Lauvau G, Geissmann F: Monitoring of blood vessels and tissues by a population of monocytes with patrolling behavior. Science (New York, NY 2007, 317:666-670.

41. Ancuta P, Rao R, Moses A, Mehle A, Shaw SK, Luscinskas FW, Gabuzda D: Fractalkine preferentially mediates arrest and migration of CD16+ monocytes. The Journal of experimental medicine 2003, 197:1701-1707.

42. Zhao C, Zhang H, Wong WC, Sem X, Han H, Ong SM, Tan YC, Yeap WH, Gan CS, Ng KQ, Koh MB, Kourilsky P, Sze SK, Wong SC: Identification of novel functional differences in monocyte subsets using proteomic and transcriptomic methods. Journal of proteome research 2009, 8:4028-4038.

43. Ancuta P, Liu KY, Misra V, Wacleche VS, Gosselin A, Zhou X, Gabuzda D: Transcriptional profiling reveals developmental relationship and distinct biological functions of CD16+ and CD16- monocyte subsets. BMC genomics 2009, 10:403.

44. Bazan JF, Bacon KB, Hardiman G, Wang W, Soo K, Rossi D, Greaves DR, Zlotnik A, Schall TJ: A new class of membrane-bound chemokine with a CX3C motif. Nature 1997, 385:640-644.

45. Harrison JK, Jiang Y, Chen S, Xia Y, Maciejewski D, McNamara RK, Streit WJ, Salafranca MN, Adhikari S, Thompson DA, Botti P, Bacon KB, Feng L: Role for neuronally derived fractalkine in mediating interactions between neurons and CX3CR1-expressing microglia. Proceedings of the National Academy of Sciences of the United States of America 1998, 95:10896-10901.

46. Truman LA, Ford CA, Pasikowska M, Pound JD, Wilkinson SJ, Dumitriu IE, Melville L, Melrose LA, Ogden CA, Nibbs R, Graham G, Combadiere C, Gregory CD: CX3CL1/fractalkine is released from apoptotic lymphocytes to stimulate macrophage chemotaxis. Blood 2008, 112:5026-5036.

47. Pan Y, Lloyd C, Zhou H, Dolich S, Deeds J, Gonzalo JA, Vath J, Gosselin M, Ma J, Dussault B, Woolf E, Alperin G, Culpepper J, Gutierrez-Ramos JC, Gearing D: Neurotactin, a membrane-anchored chemokine upregulated in brain inflammation. Nature 1997, 387:611-617.

48. Ozden S, Cochet M, Mikol J, Teixeira A, Gessain A, Pique C: Direct evidence for a chronic CD8+-T-cell-mediated immune reaction to tax within the muscle of a human T-cell leukemia/lymphoma virus type 1-infected patient with sporadic inclusion body myositis. Journal of virology 2004, 78:10320-10327.

49. Ellery PJ, Tippett E, Chiu YL, Paukovics G, Cameron PU, Solomon A, Lewin SR, Gorry PR, Jaworowski A, Greene WC, Sonza S, Crowe SM: The CD16+ monocyte subset is more permissive to infection and preferentially harbors HIV-1 in vivo. J Immunol 2007, 178:6581-6589.

50. Matsuura E, Yamano Y, Jacobson S: Neuroimmunity of HTLV-I Infection. J Neuroimmune Pharmacol 2010, 5:310-325.

51. Hanon E, Stinchcombe JC, Saito M, Asquith BE, Taylor GP, Tanaka Y, Weber JN, Griffiths GM, Bangham CR: Fratricide among CD8(+) T lymphocytes naturally infected with human $T$ cell lymphotropic virus type I. Immunity 2000, 13:657-664.

52. Enose-Akahata Y, Matsuura E, Oh U, Jacobson S: High expression of CD244 and SAP regulated CD8 T cell responses of patients with HTLV-I associated neurologic disease. PLOS pathogens 2009, 5:e1000682.

53. Ndhlovu LC, Leal FE, Hasenkrug AM, Jha AR, Carvalho KI, Eccles-James IG, Bruno FR, Vieira RG, York VA, Chew GM, Jones RB, Tanaka Y, Neto WK, Sanabani SS, Ostrowski MA, Segurado AC, Nixon DF, Kallas EG: HTLV-1 tax specific CD8+ T cells express low levels of Tim-3 in HTLV-1 infection: implications for progression to neurological complications. PLoS Negl Trop Dis 2011, 5:e1030.

54. Abdelbary NH, Abdullah HM, Matsuzaki T, Hayashi D, Tanaka Y, Takashima H, Izumo S, Kubota R: Reduced Tim-3 expression on human Tlymphotropic virus type I (HTLV-I) Tax-specific cytotoxic T lymphocytes in HTLV-I infection. The Journal of infectious diseases 2011, 203:948-959.

55. Oh U, Yamano Y, Mora CA, Ohayon J, Bagnato F, Butman JA, Dambrosia J, Leist TP, McFarland H, Jacobson S: Interferon-beta1a therapy in human Tlymphotropic virus type l-associated neurologic disease. Annals of neurology 2005, 57:526-534.

doi:10.1186/1742-4690-9-16

Cite this article as: Enose-Akahata et al:: Minocycline modulates antigenspecific CTL activity through inactivation of mononuclear phagocytes in patients with HTLV-I associated neurologic disease. Retrovirology 2012 9:16. 